\section{Management of Covid-19 Crisis At The Level Of Defence Industry}

\section{Lucian IVAN ${ }^{1} *$}

${ }^{1}$ Valahia" University, Targoviste, Dambovita County, ivan.lucian2@gmail.com

* Corresponding author
Abstract: According to estimates and analyses by the international community of economic analysts, the medical crisis generated by the Covid-19 pandemic will induce a major economic and financial crisis worldwide which, in conjunction with the current geopolitical situation, characterized by a high degree of uncertainty (e.g. strategic economic confrontation between the US and China, the position of force adopted by the Russian Federation), will affect production and supply chains, amplify the phenomenon of the adoption of trade policies of a protectionist nature, and, indirectly, will significantly affect national defense budgets.

In this fluid geopolitical context, characterized by insecurity and systemic instability, a strategic rethink and recalibration of defence policies can be predicted in a new context, defined by the multipolar competition and the asymmetry of geopolitical geometry, the conflict between civilizational models (competition between democracy vs. autocratic/totalitarian political regimes), to the detriment of regional and international collective security arrangements.

Changing government priorities generated by the pandemic crisis generated by Covid-19 may lead to a reduction in budgets for military endowment programs. Most governments allocate about $2 \%$ of GDP annually to the defence sector. Given the pandemic generated by Covid19 , there is a risk that some states will significantly reduce the budget allocated to the defence industry in order to increase the budgets for health systems, given the need to expand hospitals, as well as the purchase of medical equipment and services.

In Romania, the topic of tools and opportunities that may be able to ensure the improvement of the effects and overcoming the economic crisis is currently being discussed through active economic measures, including in the field of the defence industry. In Romania, however, the path from debate to public policy and strategy assumed and applied is traditionally long and hard, requiring more pragmatism in addressing strategic economic issues.

Keywords: management, defense industry, Covid-19, crisis, arms.

How to cite: Ivan, L. (2020). Management of Covid-19 Crisis At The Level Of Defence Industry. In M. W. Staniewski, V. Vasile, \& A. Grigorescu (vol. ed.), Lumen Proceedings: Vol. 14. International Conference Innovative Business Management \& Global Entrepreneurship (IBMAGE 2020) (pp. 270-293). Iasi, Romania: LUMEN Publishing House.

https://doi.org/10.18662/lumproc/ibmage2020/21 


\section{Introduction}

The aim of the paper is to make an "radiography" of the national defense industry in the context of the Covid-19 pandemic. In this sense, the paper aims to analyze the effects of the pandemic at the level of the international defense industry and the effects that impact the national industry, being formulated proposals to overcome this epidemiological emergency.

\section{Problem Statement}

According to estimates and analyses by the international community of economic analysts, the medical crisis generated by the Covid-19 pandemic will induce a major economic and financial crisis worldwide which, in conjunction with the current geopolitical situation, characterised by a high degree of uncertainty (e.g. strategic economic confrontation between the US and China, the position of force adopted by the Russian Federation), will affect production and supply chains, amplify the phenomenon of the adoption of trade policies of a protectionist nature, and, indirectly, will significantly affect national defence budgets.

Andrei Frolov, military expert of Valdai Club, stated that "we can state that in 2020 the world defence industry has faced its largest crisis since the end of World War II, which hasn't concluded yet. How we exit from it will depend on if a second wave of coronavirus arrives and related measures are taken, as well as the state of the economies of the world, which, as a result of this year's depression, could significantly reduce defence spending over the next two-three years" [7].

In this fluid geopolitical context, characterized by insecurity and systemic instability, a strategic rethink and recalibration of defence policies can be predicted in a new context, defined by the multipolar competition and the asymmetry of geopolitical geometry, the conflict between civilizational models (competition between democracy vs. autocratic/ totalitarian political regimes), to the detriment of regional and international collective security arrangements.

From a military security perspective, the big challenge in this new context will be to maintain commitments made, including at international level, for investment and research and development defence budgets, especially in states in hot areas in terms of geopolitical tensions. At European level, the likelihood of increased transatlantic tensions on defence industry issues, in particular between the EU and the US, in the context of the US strategic shift on domestic policy and economy issues and, externally, almost exclusively on the relationship with China, will increasingly place the 
responsibility of the tense relationship with the Russian Federation on the $\mathrm{EU}$ and, in particular, the Member States on the Eastern flank. Balancing the tense relationship with the Russian Federation to NATO member states on the Eastern flank lies in the duplicitous policy of certain EU Member States, in particular Germany and France, which maintain strong economic relations with the Russian Federation, although at the declarative level they support restrictive measures imposed on the Kremlin [8].

Now, at European Union level, the priority is to identify ways, mechanisms and instruments to exit the economic crisis that has become persistent. Thus, so far, at European level, the following means of overcoming the economic crisis have been identified: the reindustrialisation of certain socially vulnerable areas, the relocation of some manufacturing facilities, in particular from China, and the European Energy Pact ("Green Deal") [18].

A very important issue that needs to be carefully considered and which will inevitably contribute to the rebalancing of the cohesion of the Member States and the national rhythms of overcoming the crisis is the impact of these instruments and policies on the economies of each EU Member State, in particular those with intensive carbon economies and the States of Central and Eastern Europe.

It is estimated that the damage to European cohesion, the transatlantic relationship and the budgetary impact of the pandemic and the post-Covid-19 crisis will affect European strategic autonomy and European defence initiatives, namely the European Defence Fund, PESCO, Military Mobility, The European Defence Industrial Cooperation Programme, respectively, the Enhanced Tailored Presence and Enhanced Forward Presence (NATO-EU) on the Eastern flank, which will open up options in terms of deterrence capability on the Eastern flank of NATO/EU and in the evolution of the EU-Russia relationship, as well as the relationship between the Russian Federation and the Member States of the North Atlantic Alliance on the Eastern flank [13].

Particularly important will also be how the Russian Federation will position itself during the post-Covid-19 economic and political crisis. Although the hypothesis of escalation and resumption of dialogue between Europe, NATO and the Russian Federation must remain a desire for all parties, with regard to the Russian Federation, deeply affected by economic sanctions, the Covid-19 pandemic, the oil crisis and systemic dysfunctions, its geopolitical projection and its strategic objectives (e.g. restructuring of the European and global security architecture) will not be substantially influenced by the state in which Russia will be during and after the postCovid-19 crisis [3]. 
Russia has shown that it seeks, with determination, the achievement of its strategic objectives, both in times of relative stability, which provide sufficient means of achieving the objectives, and in times of deep crisis characterized by the inflaming of its geopolitical position, despite the economic difficulties, becomes a tool for diverting attention and strengthening power. In this context, we note that although the economic situation in the Russian Federation has been weakened in recent times, the President of the Russian Federation, Vladimir Putin, has strengthened his position in the polls, which has allowed the constitutional provisions to be amended to remain president [9].

The main aspect that matters in the sizing and articulation of the relationship with the Russian Federation will be the resilience and assertiveness of the central and eastern European NATO member states to the security challenges on the relationship with this state (defence capabilities, defence industry, cyber security, propaganda and counterpropaganda dimension, hybrid threats, etc.) [15].

\section{Research Questions/Aims of the research}

In addressing the issue of fundamental restructuring of the national defense industry and placing it on a competitive and sustainable basis, a number of questions need to be answered, namely:

- What kind of defense industry demands the degree of threats to national security?

- Is a technologically advanced, sectoral or basic / incremental / unsophisticated industry needed to ensure national security?

- The national defense industry must serve exclusively the basic needs of the Romanian armed forces and provide "blue collar" jobs based on the existing technological and sectoral sector, or we are considering obtaining a technologically advanced and sustainable industry only in those primary sectors. rank what can be integrated on the global circuit?

- Is the Romanian state prepared to take decisions for the fundamental restructuring of the national defense industry at the cost of political risks?

- The Romanian state is prepared to relinquish the capital / control monopoly in the national defense industry, to stimulate and integrate the private sector within the defense industry and to exercise extrinsic control and regulatory rights (eg instead of shareholding and management control), control and veto by competent authorities on significant transactions with an impact 
on national security, on the recently adopted model of the right of veto on transactions in the energy sector)?

\section{Research Methods}

The research methods of a predictive nature adopted in the scientific article are those specific to the strategic analysis, respectively SWOT for the analysis of the internal environment and PESTEL (Political, Economic, Social, Technological, Environment, Legal) for the analysis of the international environment [13].

Following the application of these analytical methods, the risks induced by the Covid-19 pandemic at the level of the international defense industry could be identified. Based on this analysis performed by the PESTEL analytical method, the risks, vulnerabilities and threats specific to the Romanian defense industry could be identified.

Based on these data and information on the national defense industry, by applying the SWOT analytical method, certain concrete proposals were identified to increase the resilience of the national defense industry, respectively action proposals for the recovery of this strategic industrial sector.

\section{Findings}

\subsection{Characteristics of the defense industry}

The analysis of the literature and available data from the exploitation of open sources of information shows the following factors influencing the global defense industry:

- The hierarchical nature of the production of weapons, depending on the technological degree and the economic competitiveness.

Depending on these two main criteria, national defense industries could be classified as grouped into 4 categories, respectively:

- Level 1 - the most advanced, flowing countries such as: USA, UK, France, Germany, Italy, Russian Federation, China;

- Level 2 - grouping countries such as: Canada, Australia, Norway, Japan, Sweden;

- Level 3 - including: Brazil, Israel, Iran, Turkey, Taiwan, Singapore, South Korea, India;

- Level 4 - represented by non-sophisticated industries without a competitive research and development base, category of which Romania is a part. 
Prior to 1990, Romania was on level 3, with trends towards level 2, given the expectation of the communist system to invest significant sums in the development of the defense industry. In this respect, we note that Romania was in the top 10 arms exporters worldwide, with values of over 800 million USD (1989).

- Defense industries are developing on the architecture of military alliances;

An example of this is NATO, which has created and adopted common standards for Member States. In this context, the defense industry in NATO member states has adopted its productive range to be able to cope with the demands from the armies of these states. From this point of view, the Romanian defense industry came late on the manufacture of weapons according to NATO standards, given both the lack of funds to invest in new production lines or the adaptation of existing ones, as well as the reluctance of political factors and managers of companies within the domestic industry.

- Impact of defense budget allocations and fundamental industry restructurings;

Over the past decades, intensive processes of concentration, specialization and efficiency of production chains have been recorded at the level of the international defense industry, in order to adapt to the challenges of military endowment. The Romanian industry has adapted more difficult to the requirements of the Armed Forces against the background of objective and subjective factors, which have encumbered the development of this sector of strategic interest. Lately there has been a greater degree of adaptability to the requirements of the internal and international market, which generates favorable premises for the development of this strategic sector.

- Influence of international arms trade;

International arms trade is one of the most dynamic businesses in terms of the funds being circulated and the variety of products offered by the defense industry. The current arms market is characterized by the high demand for modern military equipment incorporating state-of-the-art technologies. In this context, it can be said that there is fierce competition between large producers to maintain/win high-profile markets, with a consistent effort being made to control profitable markets, particularly in emerging countries such as the Middle East and Asia. Romania has lost a lot of market life given that it produces equipment that incorporates 
outdated technology, as military products are not adapted to current technologies.

- The process of globalization of industry and the expansion of production and supply chains has led to the development of dual-use industries (companies producing dual-use products and technologies, both civil and military)

This trend in the profile market has led to functional synergies between the public and private sectors, which is manifesting itself at international level. The classic weapons, controlled by the state and dedicated exclusively to ensuring security of supply for the national army, the so-called "national champions", retain a timid presence only in developing countries. Unfortunately for the Romanian industry only in the last period there is a paradigm shift in the sense that cooperation with major companies in the field has begun at international level to produce products that are part of integrated production chains. Also, at the level of the domestic defense industry, there is a trend towards the production of military equipment under the license of certain major arms manufacturers, which have outlets, as well as the funds necessary to invest in new production facilities in Romania.

- IT revolution in the military sector

At present, there is a focus on integrating civilian technological advances into the military industry and vice versa, which allows the transfer of know-how horizontally and vertically. In this context, it can be said that large arms contractors have become system contractors, with certain components or modules of armaments being worked by largely private subcontractors.

It is obvious that in the current context, characterised in recent times by a competitive multipolar geopolitical climate, we have a new factor, namely the medical, social, economic and financial crisis generated by Covid19, which will seriously impact the defence sector globally.

This projected global recession in the defense sector will have negative effects on the domestic defense industry, with certain production chains to be affected, which will cause production contraction, with profitability effects.

\subsection{Actual trends on the armament market}

The general trend in successful defense industries in developed and emerging countries lies in governments recognizing the importance and prevalence of the research \& development and high-tech products as 
elements that reduce operating costs in the defense industry and, by implication, increase economic efficiency. Consequently, these states have applied a profound restructuring of the industry and stimulated international cooperation in the field of research and technological development.

In this context, we mention some relevant examples:

- Spain: The structure and condition of the Spanish defense industry in the 80 s was identical to that of the current Romanian industry, respectively fragmented, technologically backward, inefficient, unsustainable, and owned by the State. The Spanish Government subsequently switched (following its involvement in the US f-18 fighter jet development program) to a comprehensive program to stimulate research and development $30 \%$ of Spain's total research budget allocations) whose effects ultimately exceeded the framework offered by the F-18 program by involving the Spanish industry in the European program for the Typhoon fighter jet [4].

In addition, Spain has gone from offset industrial development policy to multinational cooperation, becoming a partner in the configuration of defense systems in other countries, thus integrating into the global supply chain.

- United Kingdom: The government's economics to the national defense industry revolves around the concept of its location and not the nationality of the capital/property. The UK has massively privatized the industry and developed and refined the interdependence/partnership complex between the industrial and military, private and public sectors, as an illustrative example being the "Progress through Partnership" program launched by the British Ministry of Defense [14].

Other relevant initiatives/programs, for example, would be publicly private partnerships between the Ministry of Defense and the British defense industry (so-called Private Finance Initiatives), the "Towers of Excellence "program as an institutional partnership between the Ministry of Defense, government research institutes, private defense industry, universities with research and development concerns [20].

Speaking at a 10 Downing Street press briefing in April, the UK's most senior military official, Chief of Defence Staff General Sir Nick Carter, said: "it's important because it's at this delegated level that this works, because it makes them [the government] much more responsive, and much more flexible to respond to local demand whether it's for ambulance drivers or for testing or whatever else. With decentralisation being so much the key to the way some of this is done, the Defence Secretary delegated authority to this level early in the crisis, which has proved to be extraordinarily successful." 
- „think and act globally" - European companies in the defense industry such as BAE, EADS, Thales, Finmeccanica, MBDA are mainly focused on connecting to the integrated supply chain of the American and, increasingly, European defense industry. The share of foreign sales of these companies reaches as much as $75 \%$ of the total.

The current Eurofighter and Joint Strike Fighter-F35 programs can be used as indicators of the direction in which competitive defense industries are heading, namely, the abandonment of offset (in exchange for industrial cooperation with the local component - "local content"), international division of labor, cost reduction, promotion of research/ development and industrial clusters, reduction of industrial sovereignty, increased quality and a high technological and innovative level of products.

\subsection{Main problems identified on the level of the defense industry generated by Covid-19 pandemic}

Changing government priorities generated by the pandemic crisis generated by Covid-19 may lead to a reduction in budgets for military endowment programs. Most governments allocate about $2 \%$ of GDP annually to the defense sector. Given the pandemic generated by Covid-19, there is a risk that some states will significantly reduce the budget allocated to the defense industry in order to increase the budgets for health systems, given the need to expand hospitals, as well as the purchase of medical equipment and services. They are objective factors in the management of the Covid-19 pandemic, given that there are poor medical systems in some states that are unable to cope with this unprecedented global medical crisis.

In this context, governments are obliged to increase social expenditure and reprioritize budgetary expenditure in the light of problems in the situation of medical crisis at the level of society. Additional pressure is exerted by citizens, who, during this period, feel vulnerable and prefer that most of the funds available be used effectively to manage the pandemic crisis generated by Covid-19 [1].

To cope with the unforeseen costs of the Covid-19 pandemic, governments will use the resources initially allocated to develop the defense industry to manage the medical crisis. This leads to a considerable reduction in the defense budget, with direct effects on the endowment policy and, by implication, a decrease in the financial resources allocated to the defense industry.

In this context, in the event of the loss or even postponement of important government programs and contracts, it is necessary for companies within the defense industry to identify innovative solutions for exiting the 
crisis. A potential solution is to adapt the productive range and produce the products and equipment needed by the civil industry. In these circumstances, the Covid-19 pandemic may constitute an opportunity for the defense industry to adapt production to the area of high-performance medical equipment (e.g. the production of fans for ATI wards).

The main problems identified at the level of the defense industry, against the background of the Covid-19 pandemic are:

- maintaining specialised manpower, while reducing orders for military products and equipment;

- delay in payments to suppliers of raw materials, subassemblies and utilities, with direct effects in terms of their economic sustainability;

- the level of government aid needed to overcome the crisis caused by the Covid-19 pandemic;

- reducing the budgets allocated to research and development in favour of paying current expenditure (e.g. wages, payment of utilities and raw materials), with the risk of losing technological competition;

- relocation of production facilities, against the background of increased operational expenditure, with effects in terms of the loss of specialised human resources;

- confidence levels of investors.

"Another important problem is the decrease in stock market shares in large companies in the market. For example, from $10^{\text {th }}$ February 2020 to date, Lockheed Martin shares have decreased by $28 \%$, Leonardo $-55 \%$, Thales $-33 \%$ and Fincantieri $-32 \%$. Statistically, the shares of the biggest players in the international arms market are selling at the lowest price in five years." [19] These consequences, considered secondary, are worrying against the background in which receipts from secondary markets do not significantly affect the revenues of companies. Companies intending to issue new actions to finance capital investments were obliged to halt this project in view of the unfavorable developments in stock markets. In this context, the development plans of the companies have been reassessed in order to abandon or delay certain investments aimed at the development of these economic entities.

Furthermore, against the background of the steady and significant decline in shares, it is possible that a relevant part of them may be acquired by entities in certain countries (e.g. the Russian Federation, China) which do not have an interest in the development of the defense industry in the EuroAtlantic countries. In this context, it is necessary for governments to intervene to prevent this process, which ultimately has the role of 
bankrupting productive entities, and their market to be taken over by companies from emerging areas, especially in the Asia area.

An international actor interested in affecting or bankrupting productive entities in the Euro-Atlantic area is the Russian Federation, which will seek to take a majority stake in strong companies in the countries of interest.

\subsection{Possible scenarios for action on the level of the defense industry}

"The effects of COVID-19 on the defence industry are still to be fully understood. The impact will predominantly be on the supply chain. There are several major points of interest that could have an impact on geopolitical relations and a cascading effect on the wider defence industry, specifically with regards to supply chains and competition." [2]

If a vaccine for Covid-19 is identified within a few months, the impact of Covid-19 in the defense industry will be minimal. In this situation, only certain one-off contracts may be affected, the cancellation of certain events in the defense industry (e.g. international trade fairs/exhibitions) or the improvement of certain defense industry programs. In this situation, the defense industry as a whole will not be substantially affected and may recover within a reasonable period of time.

If the production of a viable vaccine against SARS-CoV-2 lasts longer than expected and the development of the disease worldwide is not kept under control, it can be achieved where the budget for the defense industry will be substantially reduced, which leads to damage to defense companies.

In both scenarios outlined above there is no magic solution, each company in the defense industry being obliged to adjust its own budgets, the conditions under which it operates in the profile market, the readjustment of the production chain/suppliers, and other economic and social factors.

A third possible scenario is the habit of living with this virus that causes Covid-19, in the same way that mankind has lived for thousands of years with other active viruses. In this scenario, it is unviable to pursue an endless suppression strategy, and governments and businesses will have to identify solutions to survive and redress the economic situation.

Regardless of the type of scenario, certain aspects have been identified that company managers need to consider, namely:

- the current global uncertainty generated by COVID-19 will lead to a rethinking of existing risk plans at the level of high-profile companies; 
- strategies should not focus primarily on growth, but should include more judicious resource planning and substitution of certain materials;

- the production principles should be based on maximising efficiency, while reducing production costs, by maintaining the most profitable products on the market;

- the need for technological interventions in the production chain to increase automation and the use of automated systems for the delivery of resources/components/subsystems.

Security industry companies have quickly adapted their production for delivery to the medical fan system for ATI wards, to treat the most serious cases of Covid-19, as well as means of protection (e.g. protective masks).

In this respect, we exemplify the case of UK companies - BAE SYSTEMS and BABCOCK. Thus, a significant number of contractors have adapted their modern production capabilities (e.g. 3D printers) to produce protective materials against Covid-19.

Also, in order to avoid the liquidity crisis in the production chain, large defense companies, which have significant funds, have accelerated payments to suppliers. For example, L3 HARRIS TECHNOLOGIES invested 100 million USD in accelerated payments to small providers to enable them to keep their productive activities in times of crisis.

Also in April 2020, Lockheed Martin provided 156 million USD in accelerated payments to vulnerable equipment suppliers, with 10 million USD donated to the US healthcare system.

\subsection{Characteristics of the Romanian Defense Market}

The analysis of the local market reveals certain defining characteristics that determine the profitability and sustainability of this sector of strategic interest, namely: [3]

- it is a mainly state-controlled industry, with the majority of companies operating in this field concentrated at the level of the ROMARM SA National Company, which is in coordination with the Ministry of Economy;

- chronic lack of investment and state/political control have turned it into an economically inefficient industry, against the background of a revision in making decisions based solely on economic analysis;

- the absence of any assumed political restructuring/development program through a systemic approach to the national defense industry that 
uses strengths and mitigates the consequences of systemic vulnerabilities identified at the level of this strategic sector;

- lack of coupling of the national defense industry to the national defense doctrine and to the endowment programs carried out at the level of the Ministry of National Defense;

- an autarchic industry, mainly focused on maintenance and export of primary products with no high added value and encompassing technologies from the 1980s;

- an industry absent from the global economic circuit and high-tech supply chains; the national defense industry has a timid exporter presence in certain marginal markets and only for primary, unsophisticated products, which incorporate outdated technologies;

- an industry characterized by circumstantial, opportunistic development, offset and procurement policy of the Ministry of National Defense (in most situations of military procurement concluded, the local industry plays only the role of marginal service to provide maintenance);

- technological development, by not adapting to current research and development processes at international level;

- supersizing of personnel, including situations of political "capture" by granting management and execution functions on the basis of subjective criteria;

- reduced integration into dual-use economic circuits, including through poor cooperation between state and private industries;

- redundancy and duplication with products available on the global market at lower costs.

The central element that determines the maintenance of the national defence industry, although declared a strategic sector, at this stage of return, is the autarchic governmental approach of this sector in the recital of ensuring self-sufficiency, security of supply, and the security of supply of the Romanian armed forces with basic products [4].

From the analysis of global markets, attempts to achieve selfsufficiency and total independence in the national defence industry and to ensure, at the same time, a competitive and sophisticated industry, have not been successful.

Where this approach applies (developing countries, subjects of current and immediate security threats), the budgetary cost of keeping its industry in working order is significant, this industrial sector working at a loss. 
The success of defence industries in countries such as the UK, France, Italy, Germany, Israel, Sweden, Spain or Norway demonstrates that autarchy is no longer an economic and sustainable long-term solution and that the state/government cannot control the entire supply chain.

\subsection{Impact of pandemic crisis on the level of the Romanian Defense Industry}

At the time of the Covid-19 crisis, Romania was already in a difficult fiscal situation, facing an excessive budget deficit, increasing public financial exposure, a substantial reduction in private and direct public investment, a heightened political and strategic inconsistency, a high-potential energy sector, but became a victim of populism, amid their chronic dysfunction in other important economic and social sectors.

In Romania, the topic of tools and opportunities that may be able to ensure the improvement of the effects and overcoming the economic crisis is currently being discussed through active economic measures, including in the field of the defence industry. In Romania, however, the path from debate to public policy and strategy assumed and applied is traditionally long and arduous, requiring more pragmatism in addressing strategic economic issues.

One of the instruments seen as a factor of Romania's economic recovery is reindustrialisation. In this context, it is necessary to conceptualise a national strategy identifying areas of the retrofitting of the Romanian arms industry.

The reindustrialization of Romania (including in the field of defence industry) is also a leading political theme. Therefore, in Romania, we are expected to witness political positions that will argue the allocation of resources for the "reshaping" of the national defence industry under state control, as a tool to improve the effects of the economic crisis [5].

To include reindustrialization in the range of instruments suitable for overcoming the post-Covid-19 crisis is a welcome step, but it requires, in my opinion, a new conceptualisation and approach, adapted to the 21 st century, and not a restructuring and allocation of public resources devoid of strategic vision and objectives of economic efficiency, as has happened so far. All the more so since we do not have to follow the examples of other states where industrial/economic standardization trends are expected, as a guarantee of a return from the crisis and an increase in the capacity to respond to future crises.

Whether the military and geopolitical security challenges on the Eastern flank of NATO/EU remain current with regard to Romania or not, the Romanian Defence Industry can become an important element in 
empowering the economic effort to overcome the economic and financial crisis.

The process of restructuring the national defense industry to ensure its efficiency and sustainability must be carried out based on the military alliances to which Romania is part off. Here we consider the efficiency of the national armed forces, in the context of the ability to wage war in a coalition.

A possible first counter-argument to this geopolitical "postulate" would be that such an approach would cause a greater dependence of the local defense industry and the Romanian army on external factors (supply security), which would implicitly adversely affect national security. But, as I have shown above, the absolutization of the sovereignty of the rare national industry, inevitably leads to economic autarchy and the elimination of this industry from the global supply circuit and from high tech processes.

Ultimately, the Romanian armed forces will end up making purchases exclusively from the major international contractors, without any Romanian participation. For this reason, Romania's strategic partnership with the United States of America (global leader in the field of military industry) [6] and EU membership are essential. The Romanian political factor must understand that there is no defense industry that is not dependent on external suppliers. The important thing is that the national defense industry is integrated into this supply chain.

Maintaining rare autonomous, autarchic, state-controlled water industry would require exceptionally large financial funds that the Romanian state does not have and would lead to the maintenance of an industrial base for primary, unsophisticated military products. On the contrary, it is precisely this situation that would ultimately affect the very capacity of the armed forces and, therefore, national security.

At present, we can say that the state maintains the national defense industry regardless of its economic viability, developing and producing uncompetitive weapons that can be imported at much lower costs and providing only redundant and generally low-skilled jobs.

The current legislation relevant to the national defense industry contains tools and provides rights to the competent authorities that would allow a fundamental reconfiguration of this strategic industrial sector (The National Defense Industry Act includes references to privatization, the use of European funds, industrial cooperation in associative formulas, public private partnerships, cross-border partnerships, cooperation with the private sector).

In addition to a possible fine-tuning of the existing legislative framework, the fundamental restructuring of the Romanian defense 
industry, in order to ensure a sustainable industry for the 21 st century, can take the form of a National Reform Program, politically assumed on the widest possible spectrum and implemented with rigor (i.e. precise deadlines, responsible persons/authorities, etc.), as a fundamental element of strengthening national security.

Another opportunity offered to the Covid-19 pandemic defence industry is to produce specialized equipment for the medical sector. A major advantage of defence companies is the existence of high-precision technological equipment that allows production flows to be adapted for the manufacture of high-performance products.

Thus, Mr Virgil Popescu, Minister of Economy, Energy and Business Environment, "welcomes the involvement of the national defence industry in the effort necessary to prevent and combat COVID-19". He stated that "we have already seen that Romanian isolates can be produced, and ROMARM will soon start producing masks. Now, two other companies in the national defense industry specializing in optics, one with private capital, Pro-Optica, and another with majority state capital, in the portfolio of the Ministry of Economy, optical Romanian - IOR, have joined their efforts to produce a thermal scanner in our country. I welcome these publicprivate partnerships that lead to the development of value-added products" [17].

The product, $100 \%$ Romanian design, is developed by Pro-Optica, a private company, and launched in manufacturing at IOR, a company in the Minister portfolio of Economy, Energy and Business Environment, with a military certificate issued by the Medico-Military Scientific Research Center.

At the same time, during this pandemic period, the first $100 \%$ Romanian conception isolates were made, produced by the researchers of the Ministry of National Defence, the Minister of Economy announced that the ROMARM weapons factory would produce protection masks.

\subsection{Proposals in setting up the National Defense Industry Development Program:}

1. Selective application of privatization, liquidation, private management, partnership and industrial cooperation policies (especially in the research and development area), public-private partnerships or other kind of partnerships, involving defense industry companies, giving up their inflexible and almost exclusive coupling to offset opportunities created through military procurement programs. Obviously, the reform of the defense industry must be connected to the procurement projects of the Romanian armed forces, in line with the national defense doctrine (the defense doctrine influences the structure and size of the defense industry, 
namely: the reduction of military personnel, small, complex and nontraditional contingents adapted to asymmetric, hybrid conflicts, requires a certain structure and dimension of the defense industry), but it is essential that this reform also ensures the integration of this economic sector into the global supply chain.

In case of application of the option of privatization, the State (through its economic agents) can maintain either an insignificant stake with veto or veto at institutional level (e.g. through the Supreme Defense Council of the country) on significant transactions concerning the Romanian defense industry and having potential impact on national security;

2. In the short term, stimulating the development and attracting of government and private investment for the capabilities of the defense industry that provide a limited number of competitive products (in the early stages, the technologically advanced components to be incorporated into the product are to be imported), as well as those capabilities that have potential for integration into the global high-tech market;

3. Stimulating the creation of a symbiosis (even through an institutionalized framework) between the defense industry and the private commercial sector (in the areas of $\mathrm{R} \& \mathrm{D}$, high tech); it must be definitively accepted that private firms can also make a substantial contribution to national security. In addition, private firms (competitive ones) integrate much more easily into the global economy than state-owned companies that have cumbersome and bureaucratic procedures;

4. Creating an effective partnership framework (consultation, planning), in the spirit of national defense doctrine and procurement plans, between the competent authorities controlling or/regulating the defense industry and the armed forces (the American model of dialogue and planning structured on the Department of Defense (DoD)-industry relationship, which can be an inspiration);

5. Supporting the national defense industry (once increased the degree of competitiveness and economic sustainability of this industry, thus a goal after the implementation of the Reform Program) in accessing the American and Western European markets, industrial cooperation programs with American and Western European companies; Romania's military alliance and loyalty to the US must also be reflected in the involvement of the national defense industry in American programs (e.g. Poland insisted and obtained substantial assistance and technological transfer in exchange for the location of the Patriot system on its territory) [16];

6. The stimulation of dual-use industrial capacities through the civil-military integration of the industrial base (the American Civil Military 
Integration model through the DoD Dual Use Science and Technology Program is representative in this respect);

7. Stimulating the development of $\mathrm{R} \& \mathrm{D} /$ high tech programs and capabilities (on the model of integration into global supply chains - "fit in the global supply chain"), for civilian and military projects, by entering into industrial alliances (private and public sector) with large multinational contractors (e.g. F-35 program, Tornado/Eurofighter) or with other EU Member States, with careful consideration of "fair return" mechanisms (use of local industry commensurate with the financial contribution of that State) or the choice between offset vs. competitive bidding (The Romanian government should encourage the integration of civil/commercial $R \& D$ into the defense industry, including through government-funded programs; moreover, joint R\&D programs at EU level provide an effective framework for the implementation of Article 346 of the Treaty on the Functioning of the European Union (TFEU) for purchases of complex strategic weapons (with due consideration of the argument of the essential security interest and the proportionality test), which can also resolve the dilemma of the guarantees expected by investors in industrial development programs (independent of offset) to ensure the acquisition of their products by the armed forces;

8. Stimulating the development of industrial clusters/centers of excellence on geographical grounds and preferably on the basis of crossborder industrial cooperation programs (with US and EU companies); illustrative is the dual-use industrial complex in the Toulouse region of France; at present, in Romania, we have only state industrial enclaves, inherited from the communist era, some of which are "ticked" by non-state interest groups;

\subsection{Reform of the defense industry and endowment programes of the Romanian armed forces.}

In many cases, procurement programs launched by the Romanian armed forces, especially those carried out on competitive criteria (auctions, competitive dialogue), have been delayed, blocked or failed and have created confusion and political tensions at the level of strategic alliances, with a direct impact on national security, by the lack, ultimately, of the appropriate and timely endowment of the Romanian armed forces.

The constant position of the Romanian Governments has been and is to exclusively coupling the development of the defense industry from the acquisitions of the Romanian armed forces through the offset mechanism, in order to ensure "essential security interest and security of supply". 
Where purchases are completed, the impact on defense industry (through offset programs) is, for the most part, primarily to primary assembly or maintenance services, in few cases involving the transfer of know-how, high technology or intellectual/industrial property rights.

The "efficiency" of industrial cooperation through offset programs promoted so far is reflected in the current precarious state of the defense industry.

In addition, from the perspective of the foreign investor, the industrial development of this economic sector through industrial cooperation mechanisms (through technology transfer, know-how and intellectual property rights), whether or not through offset programs related to acquisitions, is irrelevant, as long as the final customer of the product (armed forces) is not contractually secured at the time of the investment.

Investment interest becomes even lower because the technological base of the defense industry is precarious, and Romania no longer has the advantage of a skilled and cheap workforce, even a labor force available for such programs.

Even if international industrial cooperation were to be aniseed in the context of the preparatory phases of a public procurement, the same risk of insurance of the final client (under the conditions of a competitive procurement procedure) would be likely to cause reservations on the part of investors in engaging in sustainable and high-value cooperation programs for defense industry (industrial cooperation being left to the discretion of the "offset", on the basis of abstract criteria/scores, the investor opting for investments without significant economic impact and the Romanian authorities being satisfied that the figures in the offset score were ticked).

Consequently, the reversal of the current paradigm becomes a necessity, in the sense that the development of the defense industry and military procurement programs must be addressed in an integrated, simplified way, by legally defining activities of strategic importance for the defense system and national security. This would include key strategic military activities and acquisitions, within the competence of the Ministry of Defense and thus falling within the exception provided for in Article 346 TFEU and their integration with relevant industrial cooperation programs (coordinated by the Ministry of Economy, in collaboration with the Ministry of Defense) including research, design, development, technological transfer, production, integration and support of the life cycle of each strategic product, by encompassing the entire logistics chain, under conditions of security of supply.

Therefore, the key to starting the defense industry reform process also lies in coupling industrial cooperation to the armed forces' endowment 
plans once the procurement is carried out and not before or after. In other words, the Romanian army will have to acquire defense capabilities and not just products. This desire can be achieved by implementing a concept that can be defined as a "targeted industrial cooperation with multiplier effect" ("CITEM").

Such a concept would provide comfort to any investor in the defense industry by securing the end-customer, would correspond to the need to ensure security of supply for the armed forces and would contribute (by making the investment in industrial cooperation beyond the purposes of public procurement, such as, for example, for export or civil applications) to a transfer of technology, know-how and real intellectual property rights to the defense industry, with a multiplier effect.

However, such a desire cannot be achieved, in particular for strategic acquisitions, under the conditions of competitive procurement programs (industrial cooperation is often limited to indirect or direct offset, thus having an insignificant impact on the defense industry and the economy in general), often subject to a number of external political pressures, but only by applying the procedure for the direct entrustment of the procurement contract (on a case-by-case basis, and following competitive consultations with contractors selected in advance on the basis of market studies), classified as an exception to the public tendering rules pursuant to Article 346 TFEU.

From a legal perspective, CITEM would involve the systematic and in conflicting application of the relevant European legislation, the exception provided for in Article 346 TFEU, by clearly defining by law the 'essential security interest', as well as by specifying the military endowment programs which are associated with this essential security interest and, respectively, the industrial cooperation programs necessary to ensure the entire product lifecycle and the entire logistics chain.

Such a new policy of military procurement and restructuring of the defense industry calls, first and foremost, for the adoption of new legislation in this field.

A whole range of European states have implemented this concept at the legislative level, which has led to the efficient implementation of endowment programs under the conditions of international industrial cooperation programs with a localization component in the acquiring country, programs that ensure technological transfer, research, development and production and multiplier effects vertically and horizontally. 


\section{Discussions}

The scientific paper aims to present the current situation of the international and national defense industry, as well as the impact that the Covid-19 pandemic has on these strategic industrial sectors. The analytical methods that were applied in the paper (SWOT, respectively PESTEL) are purely qualitative methods that are based on the knowledge and experience of the author in the field of defense industry, there is a certain degree of uncertainty. This degree of uncertainty is also due to the fact that the data and information used come exclusively from the study of open sources, and no official data is used, which is usually confidential.

The great gain of this scientific paper is that it raises certain issues related to the defense industry, in the context of the Covid-19 pandemic, being useful to decision makers in the Ministry of Economy, respectively in the Ministry of National Defense.

From the point of view of approaching this paper, the author's experience in the field of defense industry, within the National Agency for Export Control and at the level of law enforcement within the Ministry of Internal Affairs was optimized.

Another aspect that should be noted is the discussions with experts working in the national defense industry who provided the necessary expertise to understand at a conceptual level the current problems facing the industry, especially in the current epidemiological context.

\section{Conclusions}

In conclusion, I am of the opinion that the development, modernization, increasing sustainability and integration of National Defense Industry into the global economy, while at the same time as the efficiency of the armed forces' endowment programs, would involve the implementation of the following processes:

\section{Carrying out an independent audit of the defense industry in} order to identify the vulnerabilities of this sector, the subsectors with viable potential and the non-viable / redundant ones, those with potential integration in cross-border supply chains and efficient compatibility with the endowment program of the Romanian armed forces. ensuring security of supply, tools and ways of restructuring the defense industry with minimal costs in order to stimulate industrial cooperation and technology transfer, structures and financial resources necessary to support viable subsectors that will continue their activity, the need for legislative and governmental measures, etc.; 
2. Launch of a Defense Industry Restructuring Program based on audit findings and taking into account criteria such as: integration into the global supply chain, compatibility for dual civil-military use, ensuring technology transfer, state control by veto and not by ownership, geographical industrial clusters and the conclusion of industrial alliances for local technology transfer with Western partners;

3. Adopt new legislation to define the essential security interest (except Article 346 TFEU) and stimulate the development of targeted local industrial cooperation programs with a multiplier effect for the achievement of competitive and sustainable industrial capacities.

\section{Acknowledgement}

This work is supported by project POCU 125040, entitled "Development of the tertiary university education to support the economic growth PROGRESSIO", co-financed by the European Social Fund under the Human Capital Operational Program 2014-2020.

\section{References}

[1] How COVID-19 is accelerating digital change for defence organizations [Internet]. Global Defence Technology, issue 116, October 2020 [cited 2020 Nov 5]. Available from:

https://defence.nridigital.com/global defence technology oct20/covid-19digital-change-defence.

[2] 2020 Global Defence Outlook - Growing Impact of COVID-19 [Internet]. AP News; 23 July 2020[cited 2020 Nov 5]. Available from: https://apnews.com/press-release/businesswire/cb8fccfa24e843eeb2025ba8d316cc92.

[3] Boulegue M. How is the Russian Military Responding to Covid-19? [Internet]. War on the Rocks Publication; 23 May 2020 [cited 2020 Nov 5]. Available from: https://warontherocks.com/2020/05/how-is-the-russianmilitary-responding-to-covid-19/

[4] Darling D. Spain's Defense Market and the COVID-19 Crisis [Internet]. Defense \& Security Monitor; 31 March 2020 [cited 2020 Nov 5]. Available from:https://dsm.forecastinternational.com/wordpress/2020/03/31/spains -defense-market-and-the-covid-19-crisis/

[5] Dick S, Stohl R. COVID-19 and the U.S. Defense Industry [Internet]. Stimson. 27 April 2020 [cited 2020 Nov 5]. Available from: https://www.stimson.org/2020/covid-19-and-the-u-s-defense-industry/ 
[6] Finabel European Army Interoperability Centre. How COVID-19 may impact the European Defence [Internet]. Finabel. 18 March 2020 [cited 2020 Nov 5]. Available from: https://finabel.org/how-covid-19-may-impact-theeuropean-defence/

[7] Frolov A. Finabel European Army Interoperability Centre. The Impact of the Coronavirus Epidemic on the Global Defence Industry. 24 July 2020 [cited 2020 Nov 5]. Available from: https://valdaiclub.com/a/highlights/the-coronavirus-epidemic-and-thedefence-industry/

[8] Ivan L. Doctrina Gherasimov 2.0. Revista Infosfera. 2019; 2:39-43. [cited 2020 Nov 5]. Available from:

https://www.mapn.ro/publicatii militare/arhiva infosfera/documente/201 9/2 2019.pdf

[9] Ivan L. Aspecte privind războiul hibrid rus. Revista Infosfera [Internet]. 2019; 1: 27-32 [cited 2020 Nov 5]. Available from:

https://www.mapn.ro/publicatii_militare/arhiva_infosfera/documente/201 9/1 2019.pdf

[10] Ivan L. Quo vadis industria românească de apărare? Proceedings of International Scientific Conference, "Romanian Military Thinking". Ministry of National Defense - Defense Staff. 2019; pp. 520-535. Available from: https://gmr.mapn.ro/app/webroot/fileslib/upload/files/arhiva\%20GMR/ 2019\%20gmr/Conferinta \%20GMR\%202019/GMR CONF\%20ro Ivan.pdf

[11] Ivan L. Oportunități financiare oferite de Uniunea Europeană pentru industria națională de apărare. Proceedings of International Scientific Conference of Doctoral Schools "New challenges to internal security in the European Union. Bucharest: Police Academy "Alexandru Ioan Cuza"; 2019, pp. 52-60.

[12] Ivan L. Predictive Analysis of the Romanian Defence Market. Proceeding of the International Conference The Future of Europe, Academy of Economic Studies in Bucharest - Faculty of International Economic Relations, 2019.

[13] Ivan L. Managementul analizei informațiilor. Phd [Thesis]. Targoviste: Universitatea Valahia din Targoviste; 2020. Available from: https://www.scoaladoctorala.valahia.ro/wpcontent/uploads/2018/09/Rezumat teza IVAN Lucian.pdf.

[14] Lovegrove S. MOD COVID-19 guidance to defence contractors [Internet]. TechUK, 31 March 2020 [cited 2020 Nov 5]. Available from: https://www.wiredgov.net/wg/news.nsf/articles/MOD +COVID19+guidance + to + defence $+\mathrm{c}$ ontractors +30032020124800 ?open. 
[15] Luzin P. The Influence of the Pandemic on Russia's Defense Industry [Internet]. Eurasia Daily Monitor, 17. 28 July 2020 [cited 2020 Nov 5]. Available from: https://jamestown.org/program/the-influence-of-thepandemic-on-russias-defense-industry/.

[16] Lye H. Facemasks to the frontline: how the defence industry responded to Covid-19 [Internet]. Army Technology. June 2020 [updated 2020 July 1st; cited 2020 Nov 5]. Available from: https://www.armytechnology.com/features/facemasks-to-the-frontline-how-the-defenceindustry-responded-to-covid-19/.

[17] Pachiu L. Industria de apărare în vremea pandemiei [Internet]. Hot News. 27 May 2020 [cited 2020 Nov 5]. Available from: https://economie.hotnews.ro/stiri-blogul pwc romania-24019750industria-aparare-vremea-pandemiei.htm.

[18] Sreekumar A. How COVID-19 Will Impact the Defense Industry. The Diolomar, 27 March 2020 [cited 2020 Nov 5]. Available from: https:/ / thediplomat.com/2020/03/how-covid-19-will-impact-the-defenseindustry/

[19] Tirpak J. The Defense Industry After COVID-19 [Internet]. Air Force Magazine. 1th May 2020[cited 2020 Nov 5]. Available from: https://www.airforcemag.com/article/the-defense-industry-after-covid-19/.

[20] UK Ministry of Defence. COVID-19: An Update from the Ministry of Defence Permanent Secretary [Internet]. UK; 1th May 2020 [cited 2020 Nov 5]. Available from:

https://www.gov.uk/government/organisations/ministry-of-defence. 